\title{
Acetylcholine Release and the Cholinergic Genomic Locus
}

\author{
Maurice Israël*,1 and Yves Dunant ${ }^{2}$ \\ 'Laboratoire de Neurobiologie Cellulaire et Moléculaire, C.N.R.S. F-91198 Gif-sur-Yvette, France; \\ and ${ }^{2}$ Département de Pharmacologie, Université de Genève, Centre Médical Universitaire, \\ $\mathrm{CH}-1211$ Genève-4, Switzerland
}

\begin{abstract}
Choline acetyltransferase and vesicular acetylcholine-transporter genes are adjacent and coregulated. They define a cholinergic locus that can be turned on under the control of several factors, including the neurotrophins and the cytokines. Hirschprung's disease, or congenital megacolon, is characterized by agenesis of intramural cholinergic ganglia in the colorectal region. It results from mutations of the RET (GDNF-activated) and the endothelin-receptor genes, causing a disregulation in the cholinergic locus.

Using cultured cells, it was shown that the cholinergic locus and the proteins involved in acetylcholine (ACh) release can be expressed separately ACh release could be demonstrated by means of biochemical and electrophysiological assays even in noncholinergic cells following preloading with the transmitter. Some noncholinergic or even nonneuronal cell types were found to be capable of releasing ACh quanta. In contrast, other cells were incompetent for ACh release. Among them, neuroblastoma N18TG-2 cells were rendered release-competent by transfection with the mediatophore gene. Mediatophore is an ACh-translocating protein that has been purified from plasma membranes of Torpedo nerve terminal; it confers a specificity for ACh to the release process.

The mediatophores are activated by $\mathrm{Ca}^{2+}$; but with a slower time course, they can be desensitized by $\mathrm{Ca}^{2+}$. A strictly regulated calcium microdomain controls the synchronized release of $\mathrm{ACh}$ quanta at the active zone. In addition to ACh and ATP, synaptic vesicles have an ATP-dependent $\mathrm{Ca}^{2+}$ uptake system; they transiently accumulate $\mathrm{Ca}^{2+}$ after a brief period of stimulation. Those vesicles that are docked close to $\mathrm{Ca}^{2+}$ channels are therefore in the best position to control the profile and dynamics of the $\mathrm{Ca}^{2+}$ microdomains. Thus, vesicles and their whole set of associated proteins (SNAREs and others) are essential for the regulation of the release mechanism in which the mediatophore seems to play a key role.
\end{abstract}

Index Entries: Cholinergic neurons; gene regulation; choline acetyltransferase; vesicular acetylcholine transporter; acetylcholine release, mediatophore; presynaptic proteins.

*Author to whom all correspondence and reprint requests should be addressed. 


\section{The Vesicular Acetylcholine Transporter (VAChT)}

VAChT was first identified at the genomic level by Alfonso et al. (1993) who showed that impaired cholinergic function in Coenorhabditis elegans mutants was linked to the UNC17 gene. The protein encoded showed good homology with the monoamine vesicular transporters $\mathrm{VMAT}_{1}$ and $\mathrm{VMAT}_{2}$ characterized earlier (Erikson et al., 1992; Liu et al., 1992; Schuldiner, 1992). Taking advantage of the homogenous population of cholinergic motoneurons of the Torpedo electric lobe, Varoqui et al. (1994) screened the corresponding cDNA library using a UNC17-radiolabeled probe and isolated a full-length clone. Demonstrating that the encoded putative cholinergic transporter was indeed the real acetylcholine transporter (VAChT) came from transfection experiments. Cells transfected with a plasmid encoding this transporter bound the specific blocker vesamicol with an affinity similar to that of synaptic vesicles (Varoqui et al., 1994); after loading with ACh as described by Israël et al. (1994), the transfected cells accumulated the neurotransmitter in a bound pool and this was inhibited by vesamicol (Erickson et al., 1994). The range of vesamicol concentration that inhibited transport was in agreement with previous work on isolated synaptic vesicles (Bahr and Persons, 1986a,b; Diebler and Talarmain, 1989). The kinetic parameters of ACh transport measured in PC12 cells transfected with human VAChT corresponded to those of synaptic vesicles (Varoqui and Erickson, 1996) that were purified from Torpedo electric organ by classical techniques (Israël et al., 1968, 1970, 1980; Whitlaker et al., 1972).

\section{A Cholinergic Genomic Locus}

It was interesting that the VAChT gene was located at the $5^{\prime}$ end of the noncoding region of the choline acetyltransferase (ChAT) gene (Erickson et al., 1994; Béjanin et al., 1994) at a site that was initially thought to be an intron. In neurotransmitter systems, this colocalization of two genes involved in complementary functions seems to be unique; it suggests that synthesis and storage of $\mathrm{ACh}$ are tightly controlled and coregulated (Berrard et al., 1995; Berse and Blusztajn, 1995). In humans the two genes are located on chromosomes 10 at 10q11 2 (Fig. 1). Five possible promoters for ChAT were identified in rat and a diversity of mRNA species have been characterized (Béjanin et al., 1992; Misawa et al., 1992; Wu and Hersh, 1994; Cervini et al., 1995). Such a diversity might be important for the coexpression of different phenotypes controlled by complex splicing patterns for ChAT at the level of three exons, R, $\mathrm{N}$, and $\mathrm{M}$, in the noncoding sequence. The VAChT gene is located between $\mathrm{R}$ and $\mathrm{N}$, and shares at least two R promoters with ChAT. In addition, VAChT has two specific promoters, V1 and V2 (Cervini et al., 1995).

The adjacent localization of these two genes seems typical for the cholinergic system. The VMATs genes and the genes encoding catecholamine synthesizing enzymes are not linked in a comparable way. From a general point of view, VAChT and VMATs accomplish a homologous function: They concentrate the respective transmitters in vesicles or granules by exchange for protons that were accumulated by V-ATPase. However, it should be emphasized that they operate at very different cytoplasmic concentrations. The $K_{m}$ of VMATs for monoamines is in the $\mu M$ range, whereas that of VAChT for is quite high, in the $\mathrm{m} M$ range, which corresponds to the elevated ACh concentration (20-30 $\mathrm{mM}$ ) in the cytoplasm (Dunant et al., 1974; Katz and Miledi, 1977; Morel et al., 1978). In addition, the dynamics of dopamine and noradrenaline are different since dopa-decarboxylase is in the cytoplasmic compartment whereas dopamine- $\beta$-hydroxylase in intragranular. The significance of the elevated cytosolic ACh level is certainly related to its mode of release, which might differ considerably from that of monoamines (see below).

In summary, the adjacent localization of $\mathrm{VAChT}$ and ChAT genes defines a cholinergic 


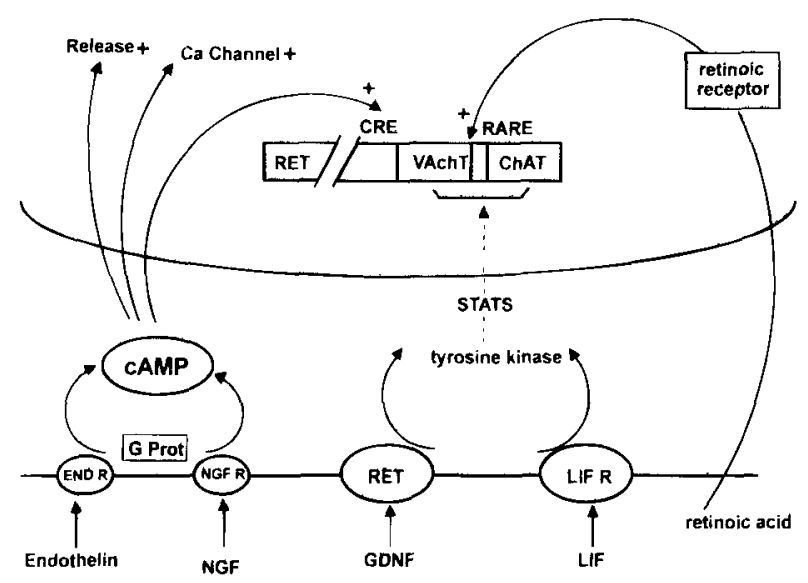

Fig. 1. Regulation of the cholinergic locus. The cholinergic locus is depicted as two adjacent genes of the human chromosome $10(10 \mathrm{q} 11.2)$ that also carries the RET gene At the cell membrane, endothelin, NGF, GDNF, and LIF interact with their respective receptors, activating either CAMP-dependent phosphorylation, or tyrosine kinase phosphorylation followed by a cascade of kinases (STATS) As a result, the cholinergic locus, the genes involved in transmitter release, and those of $\mathrm{Ca}^{2+}$-channel expression are turned on. In parallel, retinoic acid, after binding to its receptor, turns on the cholinergic locus. CRE and RARE sequences are seen at the genomic level. Mutations at the level of the GDNF/RET and of the endothelin system were found in Hirschprung's disease.

operon that is expected to be switched on in a coordinated manner in order to regulate the compartmentation of $\mathrm{ACh}$ within the neuron and adapt $\mathrm{ACh}$ metabolism to environmental changes.

The physiological role of VACht would be to increase the concentration of the transmitter and build up a store that can be mobilized in two ways.

First, if the cytoplasm becomes acidic, an immediate leakage of vesicular ACh and ATP takes place supporting $\mathrm{ACh}$ release from the cytoplasm but also the synthesis of ACh that depends of ATP. Several metabolic conditions (glycolysis for example) may acidify the cytoplasm, and signal the mobilization of vesicular ATP and ACh stores.

Second, a docked vesicle on the site of release would feed the "releasing gate" with a much higher transmitter concentration than in the cytoplasm leading to larger mepps. The essential role of VACht may be observed after vesamicol action, when the $\mathrm{ACh}$ stores are exhausted, the mechanism looses its efficacy but is still at work. Similar observations come from studies on C. elegans mutants for VACht, the $\mathrm{ACh}$ storage in vesicles seems essential to maintain release, but VACht itself is not necessary for the translocation step, that depends of a membrane gate that we discuss in a later section.

\section{Regulation of the Cholinergic Operon}

A turning point in the research of the cholinergic phenotype was made possible by the use of sympathetic neurons in culture. The factor CDF-LIF (cholinergic differentiation factor/ leukemia inhibitory factor), present in muscle conditioned-culture medium, was seen to switch off the adrenergic phenotype (i.e., a decrease in tyrosine hydroxylase) and to turn on the ChAT gene (Yamamori et al., 1989). The role of CDF-LIF was recently confirmed with the additional demonstration that VAChT was coexpressed with ChAT (Berrard et al., 1995; Berse and Blusztajn, 1995; Misawa et al., 1995; Varoqui et al., 1996). Other neuropoietic factors such as CNTF (ciliary neurotrophic factor) are also able to reroute the developmental fate of adrenergic neurons towards the cholinergic phenotype. Apparently, CDF-LIF and CNTF may seem to be unrelated cholinergic differentiation factors. However, they were shown to share a common n-helical framework that is also present in other compounds, such as hematopoietic cytokines (interleukins 6 and 3, interferons $\alpha$ and $\beta$ ); this structural homology has been recently documented by Bazan (1991).

An example in which a perturbation of the cholinergic locus leads to a severe disease is Hirschprung's congenital megacolon. Normally, cells of the neural crest migrate towards the terminal intestine forming cholinergic ganglia 
that innervate smooth muscle cells, these ganglia are absent in Hirschprung's disease. It was recently demonstrated that familial forms of Hirschprung's disease result from a mutation of the oncogene RET (Angrist et al., 1993; Lyonnet et al., 1993; Mulligan et al., 1993; Edery et al., 1996, 1994; Scuchardt et al., 1994; Pasini et al., 1995). RET is localized on human chromosome 10 (10q11 2) like VAChT and ChAT. It would therefore be interesting to know the distance separating RET from the cholinergic locus. Whatever the distance, a crucial question is why RET deletion leads to degeneration of the cholinergic ganglia of the colon. The ligand that activates RET is a factor called GDNF (glial cell line-derived neurotrophic factor) (Ibanez and Persson, 1991; Lin et al., 1993; Trupp et al., 1996). GDNF exerts a trophic influence on different classes of peripheral and central neurons, including motoneurons (Henderson et al., 1994; Oppenheim et al., 1995; Sargot et al., 1996). Mice lacking GDNF or RET do not survive since they have renal agenesis, a decreased number of neurons in several peripheral ganglia and absence of enteric neurons like in Hirschprung's disease (Moore et al., 1996; Pichel et al., 1996; Sanchez et al., 1996). The activation of RET by GDNF involves a complex multicomponent receptor (Treanor et al., 1996); it triggers tyrosine-kinase activity, leading to a cascade of phosphorylation events that results in neuron survival. This effect has been demonstrated for dopaminergic neurons and also for cholinergic motoneurons as measured by an increase in ChAT activity (Oppenheim et al., 1995; Zurn et al., 1994).

\section{Factors Controlling Presynaptic Expression of Cholinergic Genes}

Figure 1 shows that the cholinergic locus can be activated by signals coming from several different signaling pathways. As mentioned above, cytokines (CDF-LIF, CNTF) and GDNF exert their action initially through a receptor dimerization followed by the activation of a tyrosine kinase. The following cascade of bio- chemical reaction results in activation of transcription factors such as STATS (signal transducers and activators of transcription) (Curtis et al., 1994). In Hirschprung's disease, the RET tyrosine kinase link has already been mentioned, but the disease is also associated with gene defects in a different pathway, involving the endothelin-endothelin receptor system, here, the regulation occurs through a $G$ proteincoupled phosphorylation involving cAMP and protein kinase $C$. The expression of cholinergic genes might also respond to this signaling system (Salomon et al., 1996). Such a response is of particular interest since it is known that protein kinase $C$ and cAMP regulate the expression of proteins implicated in ACh release (see below).

Neurotrophins like NGF and BDNF are believed to act through other phosphorylation pathways, one of which involves the CAMPresponding system CREB-CRE (CAMP responsive element [protein]). It has been shown that cAMP up regulates both $\mathrm{ACh}$ synthesis and release in some cell lines (Blusztajn et al., 1992) and the release process in other lines (FalkVairant et al., 1996).

Still another pathway capable of switching on the cholinergic locus involves retinoic acid that binds to intracellular receptors similar to steroid or thyroxin receptors. The complex activates the expression of ChAT and VAChT at the genomic level by reacting with RARE (retinoic acid responsive elements) (Berrard et al., 1995; Berse and Blusztajn, 1995).

\section{Is Expression of the Cholinergic Locus Coordinated with That of the Release Process?}

It may be expected that the expression of ChAT and VAChT is coordinated with the expression of proteins supporting release. To test this, ACh synthesis and storage, on one side, and ACh release, on the other, must be measured separately. This experiment was recently performed by artificially filling with ACh cells that normally do not contain the neu- 
rotransmitter (Israël et al., 1994). ACh release from these cells was tested either biochemically (Israël and Lesbats, 1981) or in real-time by an electrophysiological assay. It was found in this way that many cell types that do not express ChAT and VAChT are indeed able to produce $\mathrm{Ca}^{2+}$-dependent quantal $\mathrm{ACh}$ release (Israël et al., 1994; Falk-Vairant et al., 1996a,b,c,d, 1994; Morimoto et al., 1995). This implies that the release machinery can be expressed independently of ChAT and VAChT. However, cholinergic neurons can both synthesize and release $\mathrm{ACh}$; there the two systems have to be turned on by some coordinated regulation.

For the release and its regulation, the problem is complex since many proteins are involved. The approach can be simplified by separately considering the proteins that are more specifically related to the release of ACh and those that are common to all releasing cells. The latter include voltage-gated $\mathrm{Ca}^{2+}$ channels and the components of the T- and V-SNAREs (Rothman, 1994) that govern the traffic of intracellular membranes at the active zone as they do in the Golgi apparatus. Obviously, these proteins (the T-SNAREs syntaxin and SNAP-25 at the plasma membrane, and the V-SNARE VAMP/synaptobrevin on synaptic vesicles) must be expressed in every type of cell. The same is true for V-ATPase, which functions to accumulate protons in intracellular organelles; in neurons this process is responsible for the driving force for concentrating transmitters into granules or vesicles.

In cholinergic neurons, one would expect that the expression of ChAT and VAChT is coordinated in some way to a component of the release machinery that would confer a certain specificity for $\mathrm{ACh}$. A protein supporting such $\mathrm{ACh}$ specificity has been identified and named mediatophore (see description below). However, the mediatophore was found to be a homo-oligomer of a 15-kDa proteolipid that is also a component of the membrane sector of the V-ATPase. This 15-kDa element in itself cannot therefore be considered as a cholinergic-specific protein. However, what may be more characteristic for cholinergic neurons is the mechanism that directs the $15 \mathrm{kDa}$ into the plasma membrane. This question was recently addressed by Leroy and Meunier (1995) who expressed the $15 \mathrm{kDa}$ in the Xenopus oocyte. They showed that injecting the mRNA of the $15 \mathrm{kDa}$ alone was less efficient in inducing $A C h$ release than injecting the whole set of poly $\left(A^{*}\right)$ mRNAs extracted from cholinergic neurons. In the former, the $15-\mathrm{kDa}$ protein accumulated chiefly in intracellular membranes. Therefore, another protein is probably required for directing the $15 \mathrm{kDa}$ subunit at the plasma membrane where it is assembled to form the mediatophore homo-oligomer. This process may coordinate the events associated with expression of the cholinergic locus and expression of the specific step of ACh release. In this respect, cAMP-dependent systems may be an important regulation pathway since they can upregulate both ACh synthesis and ACh release, as well as $\mathrm{Ca}^{2+}$-channels in some cells (Israël et al., 1994; Berse and Blusztajn, 1995; Falk-Vairant et al., 1996a).

\section{Calcium Microdomains and Transmitter Release}

Calcium has long been known to be the trigger for $\mathrm{ACh}$ release. By opening voltage dependent $\mathrm{Ca}^{2+}$ channels, the action potential leads to an abrupt increase of free $\mathrm{Ca}^{2+}$ at the cytoplasmic orifice of the channels. For a brief instant and in restricted areas (microdomains), $\mathrm{Ca}^{2+}$ reaches a submillimolar concentration. These $\mathrm{Ca}^{2+}$ microdomains were visualized by Llinas et al. (1992) in the squid giant synapse by using a modified, low affinity, aequorin dye. It is expected that the mechanism of neurotransmitter release that would be close to $\mathrm{Ca}^{2+}$ channels, would thus operate within microseconds in response to a relatively high $\mathrm{Ca}^{2+}$ concentration.

A second action of $\mathrm{Ca}^{2+}$ is the desensitization-or fatigue - of release Desensitization takes place at a slow rate but it requires micromolar $\mathrm{Ca}^{2+}$ concentrations. Both the $\mathrm{Ca}^{2+}$ acti- 
vation (low affinity, high speed) and the $\mathrm{Ca}^{2+}$ desensitization (high affinity, low speed) of ACh release have been demonstrated by using either intact nerve terminals, or synaptosomes, or reconstituted presynaptic membranes, or purified mediatophore incorporated in AChfilled proteoliposomes (Israël et al., 1987; Israël and Dunant, 1993; Dunant and Israël, 1995).

The kinetics and the diffusion volume of $\mathrm{Ca}^{2+}$ microdomains must be strictly controlled at the active zone. In fact, the synaptic vesicles that are docked at the membrane are in the best position to buffer local calcium. Synaptic vesicles are indeed able to actively take up $\mathrm{Ca}^{2+}$ in the presence of ATP, they can accumulate large amounts of $\mathrm{Ca}^{2+}$, to an average concentration of $20 \mathrm{mM}$ (Israël et al., 1980; Michaelson et al., 1980; Dunant et al., 1980). After a brief nerve stimulation, calcium transiently accumulates in vesicles (Fig. 2) (Parducz et al., 1987, 1994; Parducz and Dunant, 1993; Buchs and Muller, 1996; Blaustein et al., 1996). The number of exocytotic events increases significantly during the first few minutes following a period of synaptic activity (Parducz et al., 1994). This postactivity exocytosis may efficiently contribute to the process of $\mathrm{Ca}^{2+}$ extrusion. By finely tuning the local $\mathrm{Ca}^{2+}$ kinetics at the active zone, the vesicles may modulate the proportion of release sites that are open, closed, or desensitized. Conditions that impair $\mathrm{Ca}^{2+}$ sequestration are therefore expected to cause desensitization and desynchronization of release.

The perturbation of $\mathrm{Ca}^{2+}$ microdomains can have other consequences on quantal $\mathrm{ACh}$ release. Careful electrophysiological investigation using neuromuscular and nerve-electroplaque junctions revealed that the classical quantum of transmitter (approx 10,000 ACh molecules) is composed of a mean of 10 subunits (Kriebel and Gross, 1974; Kriebel, et al., 1976; Muller and Dunant, 1987; Girod et al., 1995). Individual asynchronous release of subunits (subminiature potentials) becomes prominent under conditions that alter the $\mathrm{Ca}^{2+}$ microdomain (energy shortage, exhausting stimulation, clostridial neurotoxins, and so on; (Dunant et al., 1988).
Under physiological conditions, one can hypothesize that one microdomain synchronizes the release of a mean of 10 subunits at each site. At the arrival of a nerve impulse, the simultaneous opening of all the calcium channels causes simultaneous release at the different sites. This interpretation implies that the quanta are produced instantly at the membrane by channel-like proteins synchronized by the $\mathrm{Ca}^{2+}$ microdomains. This is fundamentally different from the current theories whereby the quanta arise from the stochastic evacuation of preformed packets and the role of $\mathrm{Ca}^{2+}$ is only to increase the probability of release. One question remained: Is there in the presynaptic membrane a channel protein that would be activated at high $\mathrm{Ca}^{2+}$, slowly desensitized at low $\mathrm{Ca}^{2+}$, and would release $\mathrm{ACh}$ in a quantal manner?

\section{Mediatophore, the Acetylcholine Releasing Unit}

The starting materials for this approach were synaptosomes from the Torpedo electric organ. This population of purely cholinergic nerve terminals have been particularly useful for investigating $\mathrm{Ca}^{2+}$-dependent $\mathrm{ACh}$ release (Morel et al., 1977). In usual experiments, ACh release by synaptosomes is measured by biochemical techniques (Israël and Lesbats, 1981, 1982). It was suspected, but not established, that synaptosomes isolated from their natural environment retain the essential property of physiological release, which is to emit quanta of neurotransmitter. We addressed this question by using embryonic Xenopus myocytes as ACh detectors for real-time recording of quantal ACh release. A suspension of Torpedo electric organ synaptosomes was applied to the myocyte culture. Soon after application, we were lucky enough to record bursts of miniature potentials. These arose from pulses of ACh since they were sensitive to curare. Miniatures generated by Torpedo synaptosomes closely resembled those occurring normally during the early phase of synaptogenesis in Xenopus nerve-muscle cultures (Girod et al., 1992). 

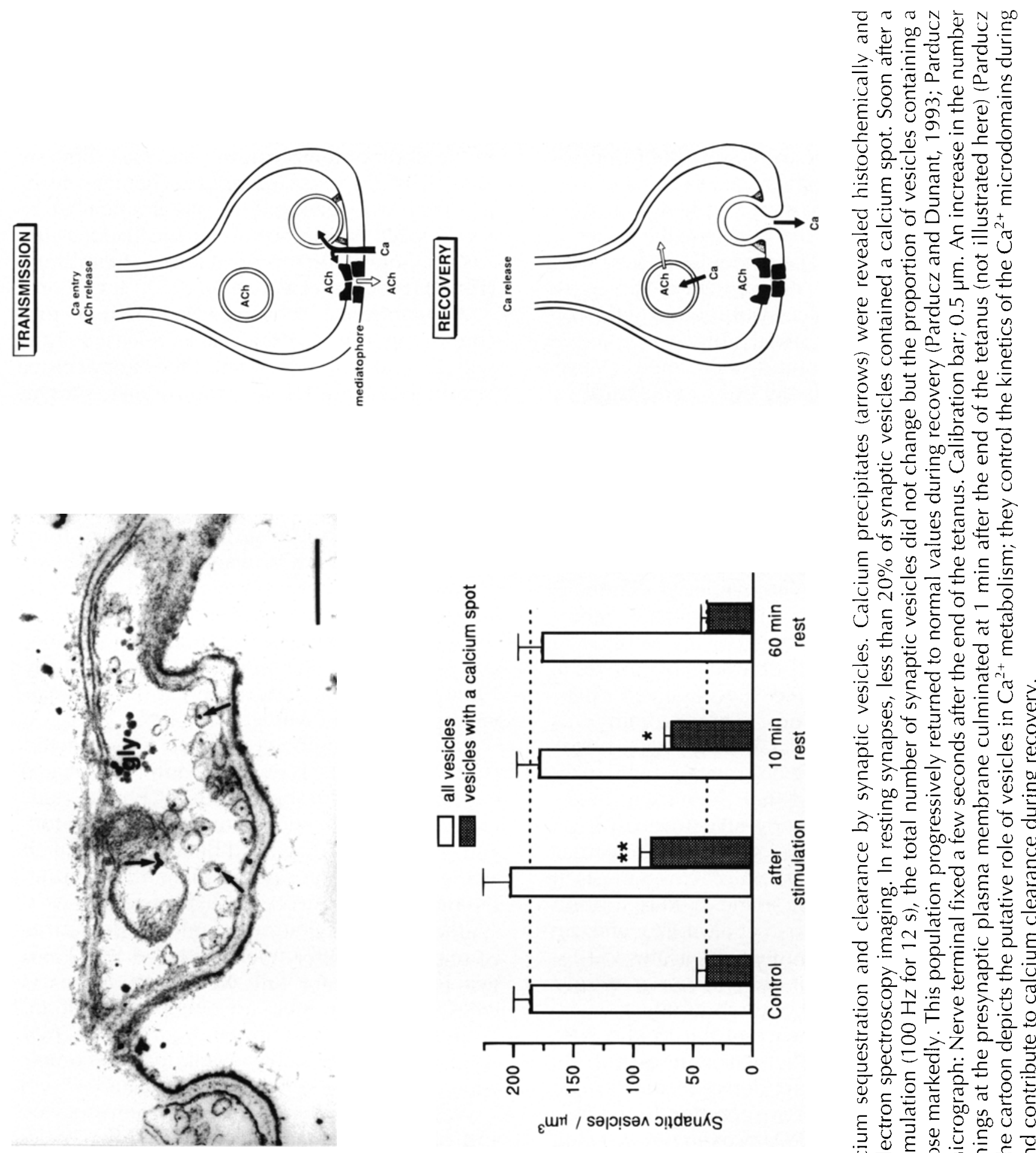

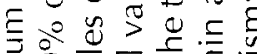

光

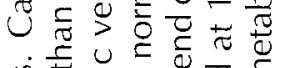

$\dot{0} \cong .000$

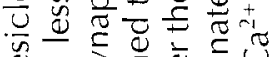

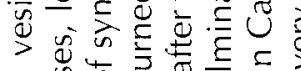

U

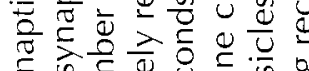

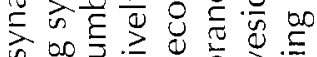

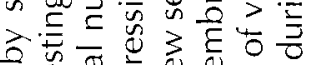

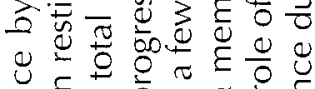

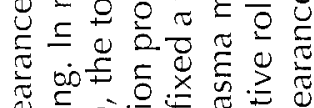

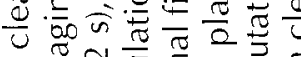

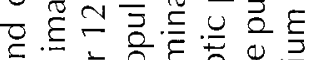

๘

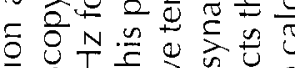

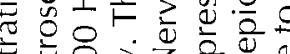

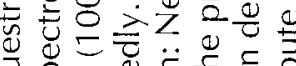

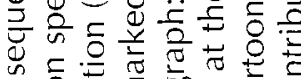

๙

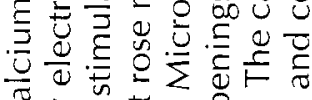

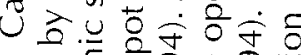

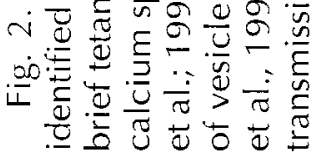

Molecular Neurobiology

Volume 16,1998 
On this basis, a long series of reconstitution experiments was undertaken with the aim to isolate the putative ACh-releasing protein. A first approach was to examine whether or not synaptosomal ghosts depleted from their vesicle and cytosolic content were still able to release the transmitter. Such ghosts were prepared from. Torpedo nerve terminals and refilled with ACh. Indeed, they were found to release the transmitter upon $\mathrm{Ca}^{2+}$ entry. The amounts released were in proportion to the $\mathrm{ACh}$ content of the ghosts (Israël et al., 1981). Reconstitution experiments of this kind were also successfully performed by using mammalian brain synaptosomes (Meyer and Cooper, 1983; Israël et al., 1988) and rat neuromuscular junction (Israël et al., 1990).

Then, the proteoliposome approach was used as a functional assay to purify the very component of the presynaptic membrane that would support $\mathrm{Ca}^{2+}$-dependent transmitter release. Fractions were prepared from the plasma membrane of Torpedo nerve terminals, reincorporated into proteoliposome membrane, and tested for release. This resulted in the identification and characterization of a lipoprotein that carried the expected AChtranslocating properties. This protein was named mediatophore (Israël et al., 1984, 1986).

Electron microscopic observation using negative staining revealed that the native mediatophore is a pentameric structure of 8- $\mathrm{nm}$ diameter with a central hole. Its molecular weight is approx $220 \mathrm{kDa}$. Since it presents itself as a homo-oligomer of single $15-\mathrm{kDa}$ subunit (Israël et al., 1984; Birman et al., 1986), one can expect that the native protein associates $15 \mathrm{sub}$ units. Each branch of the pentamer would therefore be composed of three subunits.

From a partial sequence of the $15-\mathrm{kDa}$ subunit, a nucleotide probe was synthesized. By screening a cDNA library derived from Torpedo electric lobe, a clone corresponding to the fulllength insert of the 15-kDa protein was selected and sequenced (Birman et al., 1990). It turned out that the 15-kDa subunit of the Torpedo mediatophore showed a high degree of homology with a subunit found in other transmembrane systems, such as the protonophore (c-subunit) of the bovine V-ATPase (Nelson, 1992), and a protein found in invertebrate gap junctions (Finbow et al., 1991). This 15-kDa protein appears therefore as a highly conserved element included in several different protein complexes, all involved in membrane translocation processes (Finbow et al., 1995). By using immunochemical techniques, it was seen that the oligomeric form of the Torpedo mediatophore is localized at the "active zones" of the presynaptic membrane (Fig. 3) (Brochier et al., 1993).

As mentioned above, the proteoliposomes containing the mediatophore released ACh with several typical features of the natural nerve terminals. Like natural synaptosomes, proteoliposomes containing mediatophore as unique protein released $\mathrm{ACh}$ on a $\mathrm{Ca}^{2+}$ challenge (low affinity), but release was desensitized when the proteoliposome interior was exposed to $\mathrm{Ca}^{2+}$ (high affinity) for several seconds or minutes (Israël et al., 1987). In addition, release was accompanied by the transient occurrence of large intramembrane particles in the proteoliposomes (Brochier et al., 1992), as was also observed in native synaptosomes (Israël et al., 1981) and in the natural synapses (GarciaSegura et al., 1986; Muller et al., 1987).

When the whole set of mRNAs extracted from nerve cells is injected into a Xenopus oocytes, the latter should inherit typical neuronal components such as membrane receptors and channels (Barnard and Bilbe, 1986), as well as the equipment for neurotransmitter synthesis and release. Successful expression of ACh synthesis and of neuronal ionic conductances were obtained by Gundersen et al. $(1984,1985)$ by injecting oocytes with mRNAs from electric lobes. The electric lobes are paired nuclei of the Torpedo CNS containing more than 100,000 electromotoneurons, that is, cells that are homologous to the well-known motoneurons.

We injected electric-lobe mRNAs into oocytes and demonstrated that $\mathrm{Ca}^{2+}$-dependent $\mathrm{ACh}$ release was also expressed in the primed oocytes (Cavalli et al., 1991). Like in proteoliposomes, the precise dependency of ACh release upon $\mathrm{Ca}^{2+}$ concentration and the pharmacology of release closely matched the characteristics 
When ACh-loaded cells were transfected with antisense oligonucleotides against the rat $15-\mathrm{kDa}$ mRNA proteolipid, ACh release was inhibited (Israël et al., 1994). Antisense experiments indeed suggested that the $15 \mathrm{kDa}$ is necessary for release, but many other proteins are also necessary. We were aware that the function of V-ATPase might also have been impaired, resulting in a depression of release through a vesicular mechanism. The key question was whether the mediatophore by itself would support release in a living cell, as suggested by proteoliposome experiments. To this end, we decided to transfect cells with mediatophore cDNA in order to render them able to release $\mathrm{ACh}$.

In preliminary experiments, we found that most cells can be filled by $\mathrm{ACh}$ from the external medium under appropriate conditions (Israël et al., 1994). ACh-filled cells were tested for $\mathrm{Ca}^{2+}$-dependent $\mathrm{ACh}$ release by using the luminescence method (Israël and Lesbats, 1981, 1982). In parallel experiments, some cells from the same culture were transferred into a culture of Xenopus embryonic myocytes (myoballs) that were used as sensitive and rapid detectors for the released ACh (Evers et al., 1989). Individual ACh-filled cells were moved into contact with the patched myoball and held by a fine-tipped glass pipet through which they could be electrically stimulated. Evoked ACh release was detected as nicotinic inward currents recorded from the voltage-clamped myoball. Under these conditions, certain cell lines (NG108-15; C6BU-1; L-M(TK $\left.{ }^{-}\right)$fibroblasts) released the neurotransmitter in a quantal and pulse-like manner (Fig. 4). As expected the responses were curare-sensitive and $\mathrm{Ca}^{2+}$-dependent (Falk-Vairant et al., 1996d).

Other cell lines, however, such as the mouse N18TG-2 and NIE-115 neuroblastoma cells, were unable to release ACh (Israël et al., 1994; Zhong et al., 1995a,b). Actually, N18TG-2 cells were found to be deficient in both ChAT and VAChT, the proteins controlled by the cholinergic operon (Varoqui et al., 1996; Falk-Vairant et al., 1996d). Also they contained only low levels of mediatophore in their membranes
(Israël et al., 1994). Were they release-deficient because they lacked the mediatophore? To test this, transfection of the N18TG-2 cells was performed by using a plasmid coding for the Torpedo mediatophore $15-\mathrm{kDa}$ subunit. In the transfected cells the Torpedo protein was expressed in the plasma membrane and ACh release was re-established, as assessed by both biochemical and electrophysiological determinations. On electrical stimulation, the transfected cells generated in the adjacent myoball evoked currents that were curare-sensitive, $\mathrm{Ca}^{2+}$-dependent, and displayed discrete amplitude levels, like in naturally occurring synapses (Fig. 4) (Falk-Vairant et al., 1996b,c,d).

Since N18TG-2 cells did not contain either ChAT and VAChT, it was clear that mediatophore-induced quantal release could take place in the absence of the vesicular ACh transporter. Another cell line (Neuro2A) was investigated in coculture with myocytes, the release capability being tested by the frequency of miniature potentials. Native Neuro2A cells were inefficient for release, but they became efficient after transfection with ChAT. In this case, transmitter release was also probably operative in the absence of VAChT, since the two genes of the cholinergic locus are coregulated (Zhong et al., 1995a,b).

It is concluded that provided that cells are filled with the transmitter, quantal ACh release can be demonstrated even in the absence of ChAT and VAChT. When a cell is not competent for release, transfection of mediatophore cDNA is sufficient to restore the function, including the production of pulse-like quanta.

\section{Dissociation Between Transmitter Release and Vesicle Fusion}

A time coincidence between transmitter release and vesicle fusion was only observed in exceptional situations (Parducz and Dunant, 1993; Heuser et al., 1979; Tarelli et al., 1992). In other experiments, the two processes were frankly dissociated in time (Garcia-Segura et al., 

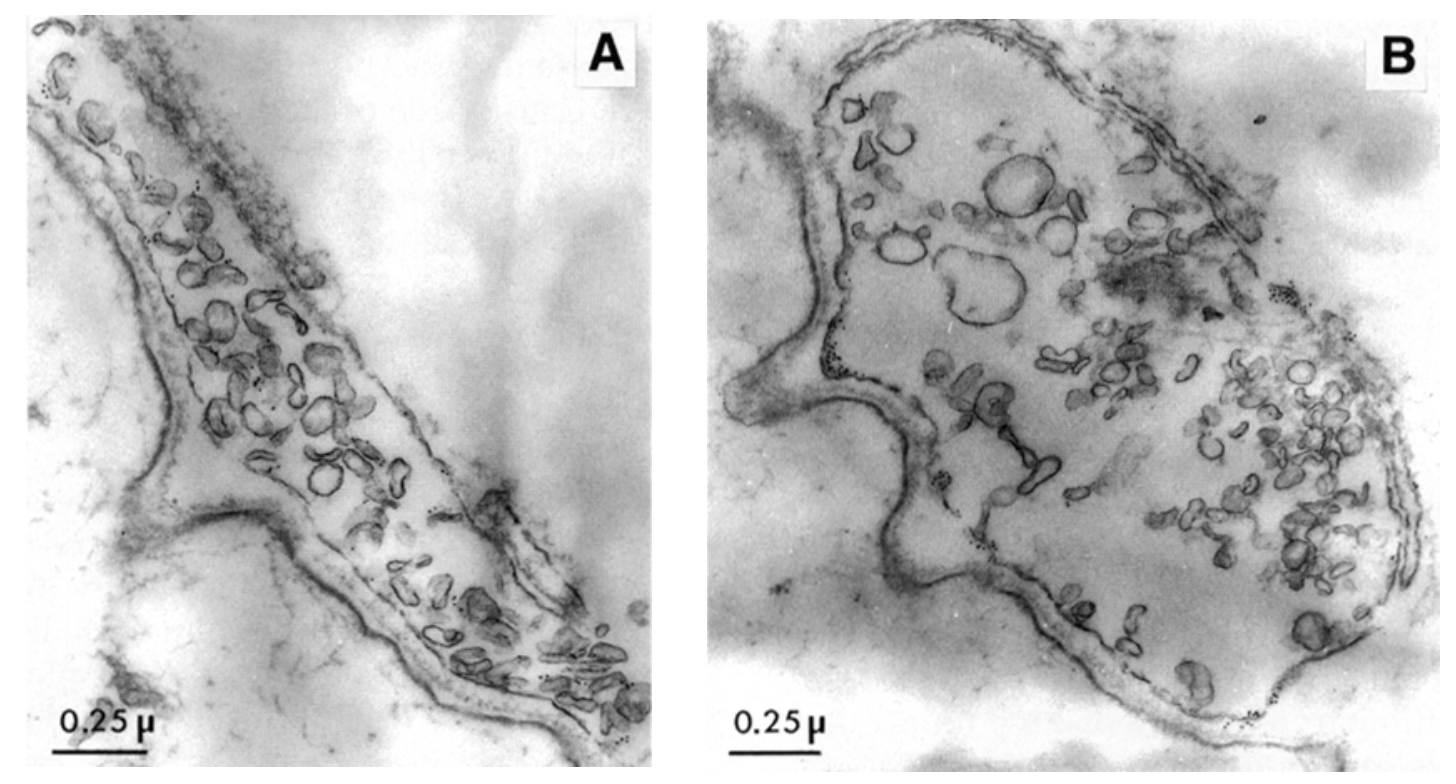

Fig. 3. Immunocytochemical localization of the vesicular acetylcholine transporter and of mediatophore in nerve terminals of the Torpedo electric organ. (A) A first anti-VAChT antibody was revealed by a gold-labeled second antibody VAChT is localized mainly in synaptic vesicles (Varoqui et al., 1995). (B) Immunocytochemical localization of mediatophore by an antibody directed against the homo-oligomer. The mediatophores form aggregates at the active zones of the plasma membrane (Brochier et al., 1993).

seen in native synapses. Importantly, the $15-\mathrm{kDa}$ subunit of the mediatophore was expressed in the membranes of the mRNA-primed oocytes but not in controls. Thus, when the release process was expressed, the mediatophore was expressed as well (Cavalli et al., 1991). Antisense oligonucleotides directed against segments of the Torpedo $15-\mathrm{kDa} \mathrm{mRNA}$ were injected into oocytes together with the total poly $\left(\mathrm{A}^{+}\right)$mRNAs of electric lobes. Strikingly, they abolished both $\mathrm{ACh}$ release and the expression of the $15-\mathrm{kDa}$ mediatophore subunit. In contrast, a $15-\mathrm{kDa}$ bovine-specific antisense probe did not affect either ACh release or the expression of the Torpedo 15-kDa subunit (Cavalli et al., 1993).

It was also shown in these experiments that the primed oocytes utilized cytosolic ACh for release. Actually, as much as $99 \%$ of the ACh content was hydrolyzed when the oocytes were disrupted in the presence of cholinesterase, demonstrating that almost all their ACh was cytosolic. This confirmed previous observations with the Torpedo nerve terminals, that the cytosolic pool of ACh is used and renewed before the vesicular pool (Dunant et al., 1972; Israël et al., 1979).

Reconstitution of ACh release in oocytes was confirmed by Alder et al. (1992) and extended to glutamate release. As we have discussed above, Leroy and Meunier (1995) obtained evidence that another protein is probably required for directing the 15-kDa subunit at the plasma membrane where it can assemble and form the mediatophore homo-oligomer.

\section{Cell Lines Competent and Incompetent for Quantal ACh Release; Correction of a Release- Deficient Cell by Mediatophore Transfection}

The antisense experiments have been repeated using a cell line (NG108-15) known to express the cholinergic release mechanism. 

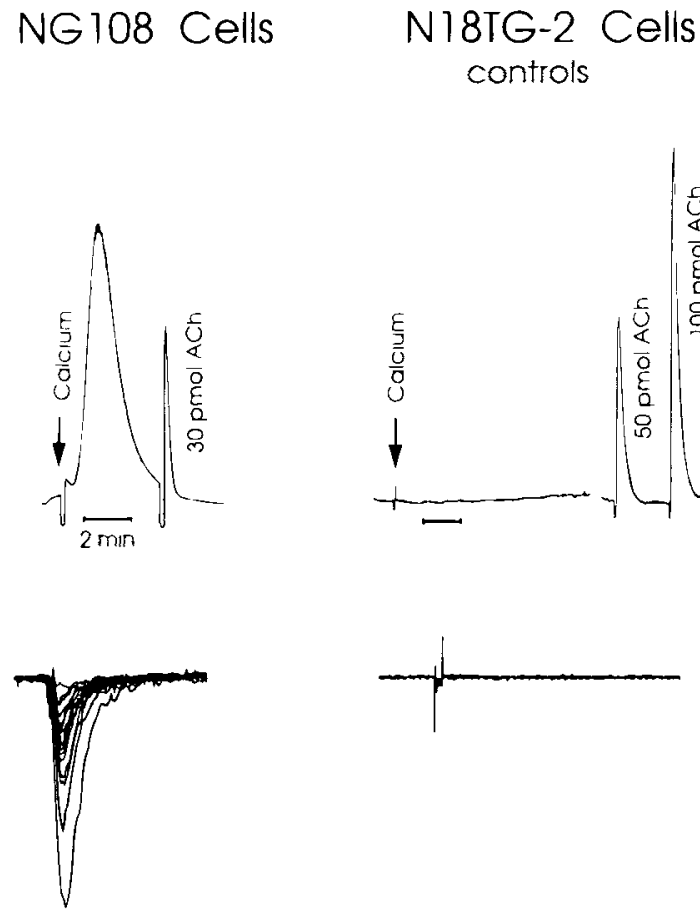
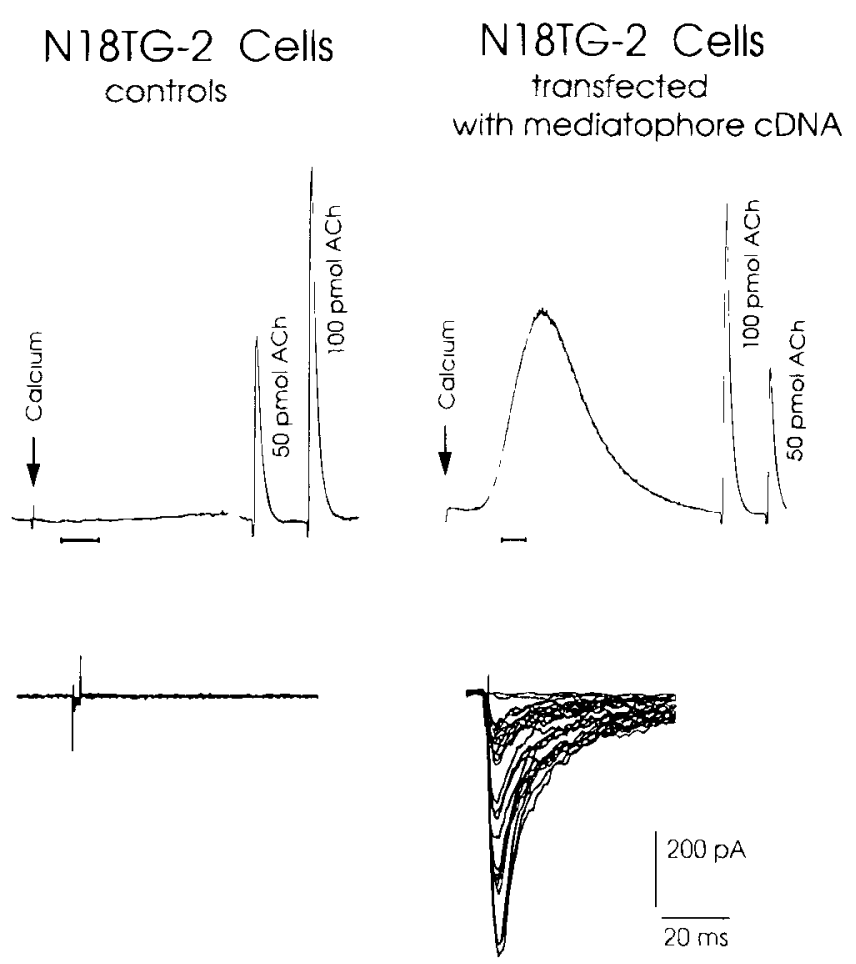

Fig. 4. Restoration of quantal release in mediatophore-transfected cells. Cells were filled overnight with ACh, washed, and then harvested to be tested for transmitter release. In the first test (upper traces), ACh release was elicited by application of the ionophore $\mathrm{A} 23187$ followed by calcium and measured by a luminescence reaction (Israël and Lesbats, 1981). In parallel, cells were applied onto a culture of embryonic Xenopus myocytes. Individual cells were pushed with an electrode against a patch-clamped myocyte and stimulated electrically. Evoked transmitter release was recorded in real time from the myocyte. Neuroblastoma $x$ glioma hybrid cells NG108 efficiently released the transmitter, but neuroblastoma N18TG-2 cells were incompetent for release. However, release could be re-established in N18TG-2 cells upon transfection with the mediatophore subunit CDNA. The electrophysiological tests showed that ACh release from transfected cells was quantal as in naturally occurring synapses (Falk-Vairant et al., 1996b,c,d).

1986; Muller et al., 1987). An example of such a dissociation was demonstrated in the Torpedo electric organ submitted to a brief nerve stimulation (100 Hz during $12 \mathrm{~s}$ ). Transmitter release took place during the first $10 \mathrm{~s}$ of the tetanus but images of vesicle fusion started to occur only after the end of activity, culminating at $1 \mathrm{~min}$ of the posttetanic recovery period (Parducz et al., 1994).

A still more dramatic dissociation between transmitter release and vesicle fusion was recently reported at the frog neuromuscular junction. Synaptic vesicles were stained with the fluorescent marker FMI-43, then the rate of "destaining" (taken as a marker for exocytosis) was monitored together with the release of transmitter during the course of nerve stimulation. Under control conditions, the kinetics of destaining was roughly parallel to the rate of release for 1-2 min (Betz and Bewick, 1993). However, staurosporine, a protein kinase $C$ inhibitor, fully abolished destaining but left synaptic transmission unaltered (Henkel and Betz, 1995).

Another example of dissociation was found in $\mathrm{Zn}^{2+}$-treated synapses of Torpedo electric organ. Incubation of small pieces of tissue in $250 \mu \mathrm{M} \mathrm{ZnCl} 2$ irreversibly blocked the release 
of ACh, but did not cause any significant alteration in the fine structure of resting nerveelectroplate junctions. Electrical stimulation at this stage resulted in $\mathrm{Ca}^{2+}$ accumulation and massive vesicle fusion despite the fact that no transmitter was released. This experimental schedule created an unusual situation where the exo-endocytotic activity of synaptic vesicles could be activated independently from the release of transmitter (Parducz et al., 1997).

\section{The SNARE Proteins and Quantal Release}

As seen above, a host of proteins associated either with synaptic vesicles or with the plasma membrane are widely distributed among neural and nonneural cells. Synaptophysin is the most abundant protein associated with vesicle membranes, but surprisingly, suppression of synaptophysin causes only a modest alteration, if any, of evoked and spontaneous quantal transmitter release (Alder et al.; 1992; Eshkind and Leube, 1995; McMahon et al., 1996). When release is reconstituted in oocytes, however, antisynaptophysin antisense oligonucleotides cause a reduction in release (Alder et al., 1992). On the other hand, alteration of proteins of the $\mathrm{V}$ - and T-SNARE family (Sollner and Rothman, 1994) affects transmission more seriously. Among these, VAMP/synaptobrevin, SNAP-25, and syntaxin are of special interest since they can be cleaved by clostridial toxins (Schiavo et al., 1992; Blasi et al., 1993), which results in interruption of the neurally evoked release of transmitter. However, some quantal transmitter release persists during the whole period of clostridial intoxication that can last for several weeks (Kriebel et al., 1976; Harris and Miledi, 1971; Thesleff et al., 1983). Moreover, evoked transmitter release can be partially restored by increasing $\mathrm{Ca}^{2+}$ entry or by using agents like latrotoxin (Molgo et al., 1990; Gansel et al., 1987). Hence, by inactivating VAMP, SNAP-25, syntaxin, and possibly other proteins, clostridial toxins uncouple the release mechanism from its natural trigger, i.e., the abrupt elevation of calcium at the above-described microdomains. The very process involved in quantal release is still operational but its $\mathrm{Ca}^{2+}$ trigger is perturbed.

Expression of the SNARE proteins was also modified or suppressed in transgenic animals. In the absence of synaptotagmin, the sensitivity of neurally evoked release was strongly inhibited, but spontaneous quantal release subsisted; it could still be greatly accelerated by hypertonicity or other techniques (Nonet et al., 1993; DiAntonio et al., 1993; Bommert et al., 1993; Broadie et al., 1995; Littleton and Bellen, 1995). A similar picture was obtained by suppressing VAMP/synaptobrevin or syntaxin (Broadie et al., 1995; Sweeney et al., 1995). The picture was therefore very similar to that of clostridial intoxication. The mechanism supporting quantal release was still present, but its $\mathrm{Ca}^{2+}$-dependent trigger was strongly perturbed. This family of proteins is therefore essential for ensuring the physiological regulation and synchronization of quantal release, but not for supporting the most elementary step of release, i.e., the formation of neurotransmitter quanta.

\section{Vesicular Docking Mechanisms}

The three proteins syntaxin, SNAP-25, and $\mathrm{VAMP} /$ synaptobrevin constitute a clostridial toxin-sensitive anchor. This complex has been purified by fractionation and immunoprecipitation experiments (Sollner et al., 1993; Shiff et al., 1996). There are, in addition, two possible systems that may anchor the vesicles to the plasma membrane, the " $\mathrm{C} 2$ » attachment and the synaptophysin-mediatophore link (Fig. 5).

Several proteins share a homologous stretch of sequence, which is the C2 domain. It is found in the vesicular protein synaptotagmin, in protein kinase $C$, and in the cytoplasmic protein, rabphilin. The latter can become associated to Rab3-GTP, and thereby to vesicle membranes. The $\mathrm{C} 2$ anchor binds directly or indirectly to the calcium channel as shown by immunoprecipitation experiments (Leveque et al., 1992; Horikawa et al., 1993). Decoy 


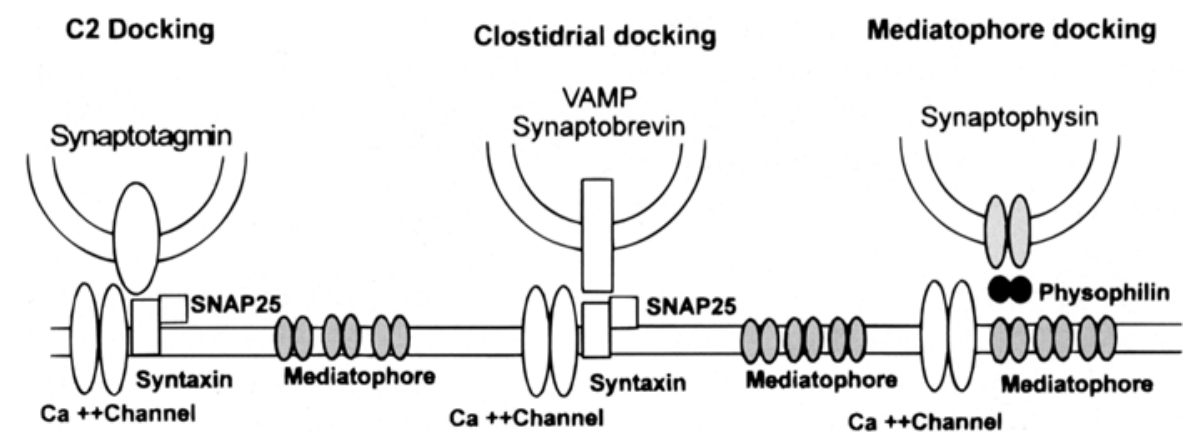

Fig. 5. Three docking links between synaptic vesicles and the plasma membrane. The " $\mathrm{C} 2$ docking" complex involves proteins with a $C 2$ sequence (such as synaptotagmin, rabphilin, protein kinase $C$, and others) and a site at, or close to, the $\mathrm{Ca}^{2+}$ channel. The "clostridial docking" complex refers to proteins that can be cleaved by botulism or tetanus toxins. They are Vamp/synaptobrevin, SNAP-25 and syntaxin. A third putative docking system involves synaptophysin, mediatophore, and physophilin.

peptides homologous to the $\mathrm{C} 2$ domain or protein kinase $\mathrm{C}$ itself, perturb this $\mathrm{C} 2$ docking and alter transmission (Bommert et al., 1993). Similarly, interference with Rab-rabphilin attachment affects release in pituitary cells (Lledo et al., 1993).

The third type of docking may involve two channel-forming proteins, synaptophysin and the mediatophore This possibility was suggested by the fact that synaptophysin (and also synaptobrevin) is immunoprecipitated with the 15-kDa protein (Galli et al., 1996), which is common to mediatophore and to the c-subunit of the $\mathrm{V}$-ATPase membrane sector $\left(\mathrm{V}_{\mathrm{o}}\right)$. In addition, another subunit of V-ATPase (39 kDa) was previously identified as physophilin, a synaptophysin-binding protein (Thomas and Betz, 1990; Siebert et al., 1994). This docking system might link, in series through mediatophore and synaptophysin- $V_{0}$, the vesicle lumen to the extracellular space. This link is expected to be resistant to clostridial toxins. It may still function, like the $\mathrm{C} 2$ anchor, when the clostridial anchor (T- and V-SNAREs) is absent or cut. In fact, vesicles still dock to the membrane when the clostridial link is damaged (Broadie et al., 1995). However, a physiologically intact clostridial link is likely to be essential for controlling the shape and kinetics of the $\mathrm{Ca}^{2+}$ microdomains, ensuring synchroniza- tion of release, and protecting mediatophore against desensitization.

\section{Conclusions}

In order to control a cholinergic phenotype, a neuron has to turn on the cholinergic locus but also must express the mediatophore at the plasma membrane in order to support quantal release of ACh. Synchronization of release with respect to the calcium trigger is regulated by a set of proteins that dock the vesicles at the active zones (Couteaux and PécotDechavassine, 1970). The docked vesicles are expected to control the shape and the kinetics of $\mathrm{Ca}^{2+}$ microdomains. The latter regulation is independent of the cholinergic phenotype since it is found in all synapses.

From the work of Zimmermann and Denston (1977) we may consider that vesicle recycling is an essential feature of synaptic function since transmission would rapidly stop if recycling was blocked. Moreover knowledge of protein-protein interactions that support the dynamics of endo-exocytosis are now well documented by the work of Sudhof (1995). These essential contributions are compatible with our own views on the role of an inevitable gate, probably mediatophore, that supports 
the final translocation steps of release: the delivery of the smallest quantum of ACh.

\section{Acknowledgments}

Real-time recording of transfected cells was initiated by our friend and colleague, Jean Falk-Vairant who died in a car accident on November 21, 1994. We are grateful to Ann and Gabor Kato for helpful criticism and to our coworkers for support, discussions, and some unpublished data. Work in our laboratories was supported by the Swiss F.N.R.S. (Grant No 31.47286.96) to Y.D. and French A.F.M. and D.R.E.T. grants to M.I.

\section{References}

Alder J., Xie X., Valtorta F., Greengard P., and Poo M. M. (1992) Antibodies of synaptophysin interfere with transmitter secretion at neuromuscular synapses. Neuron 9, 759-768.

Alder J., Lu B., Valtorta F., Greengard P., and Poo M. M. (1992) Calcium-dependent transmitter secretion reconstituted in Xenopus oocytes: requirement for synaptophysin. Science 257, 657-661.

Alfonso A., Grundahl K., Duerr J. S., Han H. P., and Rand J. B. (1993) The Caenorhabditis elegans unc-17 gene: a putative vesicular acetylcholine transporter. Science 261, 617-619.

Angrist M., Kauffman E., Slaugenhaupt S. A., Matise T. C., Puffenberger E. G., Washington S. S., Lipson A., Cass D. T., Reyna T., Weeks D. E., et al. (1993) A gene for Hirschsprung disease (megacolon) in the pericentromeric region of human chromosome 10. Nat. Genet. 4, 351-356.

Béjanin S., Habert E., Berrard S., Edwards J. B., Loeffler J. P., and Mallet J. (1992) Promoter elements of the rat choline acetyltransferase gene allowing nerve growth factor inducibility in transfected primary cultured cells. J. Neurochem. 58, 1580-1583.

Béjanin S., Cervini R., Mallet J., and Berrard S. (1994) A unique gene organization for two cholinergic markers, choline acetyltransferase and a putative vesicular transporter of acetylcholine. J. Biol. Chem. 269, 21,944-21,947.
Bahr B. A. and Parsons S. M. (1986a) Acetylcholine transport and drug inhibition kinetics in Torpedo synaptic vesicles. J. Neurochem. 46, 1214-1218.

Bahr B. A. and Parsons S. M. (1986b) Demonstration of a receptor in Torpedo synaptic vesicles for the acetylcholine storage blocker L-trans-2-(phenyl $\left[3,4{ }^{3} \mathrm{H}\right]$ piperidino) cyclohexanol. Proc. Natl. Acad. Sci. USA 83, 2267-2270.

Barnard E. A. and Bilbe G. (1986) Functional expression in the Xenopus oocyte of the mRNAs for receptors and ion channels, in Neurochemistry, $A$ Practical Approach (Turner, A. J. and Bachelard H. S., eds.) IRL Press, Oxford, pp. 243-270.

Bazan J. F. (1991) Neuropoietic cytokines in the hematopoietic fold. Neuron. 7, 197-208.

Berrard S., Varoqui H., Cervini R., Israël M., Mallet J., and Diebler M.-F. (1995) Coregulation of two embedded gene products, choline acetyltransferase and the vesicular acetylcholine transporter. J. Neurochem. 65, 939-942.

Berse B. and Blusztajn J. K. (1995) Coordinated up-regulation of choline acetyltransferase and vesicular acetylcholine transporter gene expression by the retinoic acid receptor alpha, CAMP, and leukemia inhibitory factor/ciliary neurotrophic factor signaling pathways in a murine septal cell line. J. Biol. Chem. 270, 22,101-22,104.

Betz W. J. and Bewick G. S. (1993) Optical monitoring of transmitter release and synaptic vesicle recycling at the frog neuromuscular junction. J. Physiol. Lond. 460, 287-309.

Birman S., Israël M., Lesbats B., and Morel N. (1986) Solubilization and partial purification of a presynaptic membrane protein ensuring calciumdependent acetylcholine release from proteoliposomes. J. Neurochem. 47, 433-444.

Birman S., Meunier F. M., Lesbats B., LeCaer J. P. LeCaer, Rossier, J. and Israël M. (1990) A 15 kD proteolipid found in mediatophore preparations from Torpedo presents high sequence homology with the bovine chromaffin granule protonophore. FEBS Lett. 261, 303-306.

Blasi J., Chapman E. R., Link E., Binz T., Yamasaki S., De Camilli P., Sudhof T. C., Nieman H., and Jahn R. (1993) Botulinum neurotoxin A selectively cleaves the synaptic protein SNAP-25. Nature 365, 160-163.

Blaustein M. P., Church P. J., and Stanley E. F. (1996) Localization of ion transporters involved in calcium control in presynaptic nerve terminals. Soc. for Neurosc. Abstr. 22, 323. 
Blusztajn J. K., Venturini A., Jackson D. A., Lee H. J., and Wainer B. H. (1992) Acetylcholine synthesis and release is enhanced by dibutyryl cyclic AMP in a neuronal cell line derived from mouse septum. J. Neurosci. 12, 793-799.

Bommert K., Charlton M. P., DeBello W. M., Chin G. J., Betz H., and Augustine G. J. (1993) Inhibition of neurotransmitter release by $\mathrm{C} 2$-domain peptides implicates synaptotagmin in exocytosis. Nature 363, 163-165.

Broadie K., Prokop A., Bellen H. J., O'Kane C. J., Schulze K. L., and Sweeney S. T. (1995) Syntaxin and synaptobrevin function downstream of vesicle docking in Drosophila. Neuron 15, 663-673.

Brochier G., Gulik-Krzywicki T., Lesbats B., Dedieu J., and Israël M. (1992) Calcium-induced acetylcholine release and intramembrane particle occurrence in proteoliposomes equipped with mediatophore. Biol. Cell 74, 225-230.

Brochier G., Israël M., and Lesbats B. (1993) Immunolabelling of the presynaptic membrane of Torpedo electric organ nerve terminals with an antiserum towards the acetylcholine releasing protein mediatophore. Biol. Cell 78, 145-154.

Buchs P. A. and Muller D. (1996) Induction of longterm potentiation is associated with major ultrastructural changes of activated synapses. Proc. Natl. Acad. Sci. USA 93, 8040-8045.

Cavalli A., Eder-Colli L., Dunant Y., Loctin F., and Morel N. (1991) Release of acetylcholine Xenopus oocytes injected with nRNAs from cholinergic neurons. EMBO J. 10, 1671-1675.

Cavalli A., Dunant Y., Leroy C., Meunier F. M., Morel N., and Israël M. (1993) Antisense probes against mediatophore block transmitter release in oocytes primed with neuronal mRNAs. Eur. J. Neturosci. 5, 1539-1544.

Cervini R., Houhou L., Pradat P. F., Béjanin S., Mallet J., and Berrard S. (1995) Specific vesicular acetylcholine transporter promoters lie within the first intron of the rat choline acetyltransferase gene. J. Biol. Chem. 270, 24,654-24,657.

Couteaux R. and Pécot-Dechavassine M. (1970) Vésicules synaptiques et poches au niveau des "zones actives" de la jonction neuromusculaire. C.R. Acad. Sci. Paris 271, 2346-2349.

Curtis R., Scherer S. S., Somogyi R., Adryan K. M., Ip N. Y., Zhu Y., Lindsay R. M., and DiStefano P. S. (1994) Retrograde axonal transport of LIF is increased by peripheral nerve injury: correla- tion with increased LIF expression in distal nerve. Neuron. 12, 191-204.

DiAntonio A., Parfitt K. D., and Schwarz T. L. (1993) Synaptic transmission persists in synaptotagmin mutants of Drosophila. Cell 73, 1281-1290.

Diebler M. F. and Morot Gaudry Talarmain Y. (1989) AH5183 and cetiedil: two potent inhibitors of acetylcholine uptake into isolated synaptic vesicles from Torpedo marmorata. J. Neurochem. 52, 813-821.

Dunant Y. and Israël M. (1995) Mediatophore and other presynaptic proteins. A cybernetic linking at the active zone. J. Physiol. Paris 89, 147-156.

Dunant Y., Gautron J., Israël M., Lesbats B., and Manaranche R. (1972) Les compartiments d'acétylcholine de l'organe électrique de la Torpille et leurs modifications par la stimulation. I. Neurochem. 19, 1987-2002.

Dunant Y., Gautron J., Israël M., Lesbats B., and Manaranche R. (1974) Evolution de la décharge de l'organe électrique de la Torpille et variations simultanées de l'acétylcholine au cours de la stimulation. J. Neurochem. 23, 635-643.

Dunant Y., Babel-Guérin E., and Droz B. (1980) Calcium metabolism and acetylcholine release at the nerve-electroplaque junction. J. Physiol. Paris $76,471-478$.

Dunant Y., Loctin F., Marsal J., Muller D., Parducz A., and Rabasseda X. (1988) Energy metabolism and quantal acetylcholine release. Effects of botulinum toxin, fluorodinitrobenzene and diamide in the Torpedo electric organ. I. Neurochem. 50, 431-439.

Edery P., Pelet A., Mulligan L. M., Abel L., Attie T., Dow E., Bonneau D., David A., Flintoff W., Jan D., et al. (1994) Long segment and short segment familial Hirschsprung's disease: variable clinical expression at the RET locus. J. Med. Genet. 31, 602-606.

Edery P., Attie T., Amiel J., Pelet A., Eng C., Hofstra R. M., Martelli H., Bidaud C., Munnich A., and Lyonnet S. (1996) Mutation of the endothelin-3 gene in the Waardenburg-Hirschsprung disease (Shah-Waardenburg syndrome). Nat. Genet. 12, 442-444.

Erickson J. D., Eiden L. E., and Hoffman B. J. (1992) Expression cloning of a reserpine-sensitive vesicular monoamine transporter Proc. Natl. Acad. Sci. USA 89, 10,993-10,997.

Erickson J. D., Varoqui H., Schafer M. K., Modi W., Diebler M. F., Weihe E., Rand J., Eiden L. E., 
Bonner T. I., and Usdin T. B. (1994) Functional identification of a vesicular acetylcholine transporter and its expression from a "cholinergic" gene locus. J. Biol. Chem. 269, 21,929-21,932.

Eshkind L. G. and Leube R. E. (1995) Mice lacking synaptophysin reproduce and form typical synaptic vesicles. Cell Tissue Res. 282, 423-433.

Evers J., Laser M., Sun Y., Xie Z., and Poo M. M. (1989) Studies of nerve-muscle interactions in Xenopus cell culture: analysis of early synaptic currents. J. Neurosci. 9, 1523-1539.

Falk-Vairant J., Dunant Y., and Israël M. (1994) Quantal acetylcholine release in reconstituted systems. J. Neurochem. 63, S90.

Falk-Vairant J., Israël M., Bruner J., Stinnakre J., Meunier F. M., Gaultier P., Meunier F. A., Lesbats B., Synguelakis M., Corrèges $P_{\text {., }}$ and Dunant, $Y$. (1996a) Evoked transmitter release from fibroblasts loaded with acetylcholine, enhancement by cAMP. Neuroscience 75, 353-360.

Falk-Vairant J., Meunier F. M., Lesbats B., Corrèges P., Eder-Colli L., Salem N., Synguelakis M., Dunant Y., and Israël M. (1996b) Cell lines expressing an acetylcholine release mechanism, correction of a release-deficient cell by mediatophore transfection. J. Neurosc. Res. 45, 195-201.

Falk-Vairant J., Corrèges P., Eder-Colli L., Salem N., Meunier F., Lesbats B., Loctin F., Synguelakis M., Israël M., and Dunant Y. (1996c) Evoked acetylcholine release expressed by transfection of mediatophore cDNA. J. Neurochem. 66, 1322-1325.

Falk-Vairant J., Corréges P., Eder-Colli L., Salem N., Roulet E., Bloc A., Meunier F., Lesbats B., Loctin F., Synguelakis M., Israël M., and Dunant $Y$. (1996d) Quantal acetylcholine release induced by mediatophore transfection. Proc. Natl. Acad. Sci. USA 93, 5203-5207.

Finbow M. E., Pitts J. D, Goldstein D. J, Schlegel R., and Findlay B. C. (1991) The E5 oncoprotein target: a $16-\mathrm{kDa}$ channel- forming protein with diverse functions. Molec. Carcinog. 4, 441-444.

Finbow M. E., Harrison M., and Jones P. (1995) Ductin-a proton pump component, a gap junction channel and a neurotransmitter release channel. Bioessays 17, 247-255.

Galli T., McPherson P. S., and De Camilli P. (1996) The Vo sector of the VATPase, synaptobrevin, and synaptophysin are associated on synaptic vesicles in a Triton X-100-resistant, freeze-thawing sensitive, complex. J. Biol. Chem. 271, 2193-2198.
Gansel M., Penner R., and Dreyer F. (1987) Distinct sites of action of clostridial neurotoxins revealed by double-poisoning of mouse motor nerve terminals. Pfliigers Arch. 409, 533-539.

Garcia-Segura L. M., Muller D., and Dunant Y. (1986) Increase in the number of presynaptic large intramembrane particles during synaptic transmission at the Torpedo nerve-electroplaque junction. Neuroscience 19, 63-79.

Girod R., Eder-Colli L., Medilanski J., Dunant Y., Tabti N., and Poo M. M. (1992) Pulsatile release of acetylcholine by nerve terminals (synaptosomes) isolated from the Torpedo electric organ. J. Physiol. Lond. 450, 325-340.

Girod R., Corrèges P., Jacquet J., and Dunant Y. (1993) Space and time characteristics of transmitter release at the nerve-electroplaque junction of Torpedo. J. Physiol. Lond. 471, 129-157.

Gundersen C. B., Miledi R. B., and Parker I. (1984) Slowly inactivating potassium channels induced in Xenopus oocytes by messenger ribonucleic acid from Torpedo brain. J. Physiol. Lond. 353, 231-248.

Gundersen C. B., Jenden D. J., and Miledi R. B. (1985) Choline acetyltransferase and acetylcholine in Xenopus oocytes injected with mRNA from the electric lobe of Torpedo. Proc. Natl. Acad. Sci. USA 82, 608-611.

Harris A. J. and Miledi R. B. (1971) The effect of type D botulinum toxin on frog neuromuscular junctions. J. Physiol. Lond. 217, 497-515.

Henderson C. E., Phillips H. S., Pollock R. A., Davies A. M., Lemeulle C., Armanini M., Simmons L., Moffet B., Vandlen R. A., Simpson L. C., Koliastos V. E., and Rosenthal A. (1994) GDNF: a potent survival factor for motoneurons present in peripheral nerve and muscle. Science 266, 1062-1064.

Henkel A. W. and Betz W. J. (1995) Staurosporine blocks evoked release of FM1-43 but not acetylcholine from frog motor terminals. J. Neurosc. 15, 8246-8258.

Heuser J. E., Reese T. S., Dennis M. J., Jan Y., Jan L., and Evans L. (1979) Synaptic vesicle exocytosis captured by quick freezing and correlated with quantal transmitter release. J. Cell. Biol. 81, 275-300.

Horikawa H. P., Saisu H., Ishizuka T., Sekine Y., Tsugita A., Odani S., and Abe T. (1993) A complex of rab3A, SNAP-25, VAMP/synaptobrevin-2 and syntaxins in brain presynaptic terminals. FEBS Lett. 330, 236-240. 
Ibanez C. F. and Persson H. (1991) Localization of sequences determining cell type specificity and NGF responsiveness in the promoter region of the rat choline acetyltransferase gene. Eur. J. Neurosci. 3, 1309-1315.

Israël M. and Dunant Y. (1993) Acetylcholine release, from molecules to function. Prog. Brain Res. 98, 219-233.

Israël M. and Lesbats B. (1981) Continuous determination by a chemiluminescent method of acetylcholine release and compartmentation in Torpedo electric organ synaptosomes J. Neurochem. 37, 1475-1483.

Israël M. and Lesbats B. (1982) Application to mammalian tissues of the chemiluminescent method for detecting acetylcholine. J. Neurochen. 39, 248-250.

Israël M., Gautron J., and Lesbats B. (1968) Isolement des vésicules synaptiques de l'organe électrique de la Torpille et localisation de l'acétylcholine à leur niveau. C.R. Acad. Sci. Paris 266, 273-275.

Israël M., Gautron J., and Lesbats B. (1970) Fractionnement de l'organe électrique de la Torpille: localisation subcellulaire de l'acétylcholine. J. Neurochem. 17, 1441-1450.

Israël M., Dunant Y., and Manaranche R. (1979) The present status of the vesicular hypothesis. Prog. Neurobiol. 13, 237-275.

Israël M., Manaranche R. F. M., Morel N., Frachon P., and Lesbats B. (1980) ATP-dependent calcium uptake by cholinergic synaptic vesicles isolated from Torpedo electric organ. J. Menbr. Biol. 54, 115-126.

Israël M., Lesbats B., and Manaranche R. (1981) ACh release from osmotically shocked synaptosomes refilled with transmitter. Nature 294, 474-475.

Israël M., Manaranche R., Morel N., Dedieu J., Gulik-Krzywicki T., and Lesbats B. (1981) Redistribution of intramembrane particles related to acetylcholine release by cholinergic synaptosomes J. Ultrastruct. Res. 75, $162-178$.

Israël M., Lesbats B., Morel N., Manaranche R., Gulik-Krzywicki T., and Dedieu J. (1984) Reconstitution of a functional synaptosomal membrane possessing the protein constituents involved in acetylcholine translocation. Proc. Natl. Acad. Sci. USA 81, 277-281.

Israël M., Morel N., Lesbats B., Birman S., and Manaranche R. (1986) Purification of a presynaptic membrane protein that mediates a calcium- dependent translocation of acetylcholine. Proc. Natl. Acad. Sci. USA 83, 9226-9230.

Israël M., Meunier F. M., Morel N., and Lesbats B. (1987) Calcium-induced desensitization of acetylcholine release from synaptosomes or proteoliposomes equipped with mediatophore, a presynaptic membrane protein. J. Neurochem. 49, 975-982.

Israël M., Lesbats B., Morel N., Manaranche R., and Le Gal la Salle G. (1988) Is the acetylcholine releasing protein mediatophore present in rat brain? FEBS Lett. 233, 421-426.

Israël M., Lesbats B., Sbia M., and Morel N. (1990) Acetylcholine translocating protein: mediatophore at rat neuromuscular synapses. J. Neurochem. 55, $1758-1762$.

Israël M., Lesbats B., Synguelakis M., and Joliot A. (1994) Acetylcholine accumulation and release by hybrid NG108-15, glioma and neuroblastoma cells-Role of a $16 \mathrm{kDa}$ membrane protein in release. Neurochem. Int. 25, 103-109.

Katz B. and Miledi R. B. (1977) Transmitter leakage from motor nerve endings. Proc. R. Soc. London. B. 196, 59-72.

Kriebel M. E. and Gross C. E. (1974) Multimodal distribution of frog miniature endplate potentials in adult, denervated and tadpole leg muscle. J. Gen. Physiol. 64, 85-103.

Kriebel M., Llados E. F., and Matteson D. R. (1976) Spontaneous subminiature end-plate potentials in mouse diaphragm muscle: evidence for synchronous release. J. Physiol. Lond. 262, 553-581.

Leroy C. and Meunier F. M. (1995) Differential targeting to the plasma membrane of the Torpedo $15-\mathrm{kDa}$ proteolipid expressed in oocytes. J. Neurochem. 65, 1789-1797.

Leveque C., Hoshino T., David P., Shoji-Kasai Y., Leys K., Omori A., Lang B., El Far O., Sato K., Martin Moutot N., et al. (1992) The synaptic vesicle protein synaptotagmin associates with calcium channels and is a putative LambertEaton myasthenic syndrome antigen. Proc. Natl. Acad. Sci. USA 89, 3625-3629.

Lin L. F., Doherty D. H., Lile J. D., Bektesh S., and Collins F. (1993) GDNF: a glial cell line-derived neurotrophic factor for midbrain dopaminergic neurons. Science 260, 1130-1132.

Littleton J. T. and Bellen H. J. (1995) Synaptotagmin controls and modulates synaptic-vesicle fusion in a $\mathrm{Ca}(2+)$-dependent manner. Trends Neurosci. 18, 177-183.

Liu Y., Peter D., Roghani A., Schuldiner S., Prive G. G., Eisenberg D., Brecha N., and Edwards R. H. 
(1992) A cDNA that suppresses MPP+ toxicity encodes a vesicular amine transporter. Cell $\mathbf{7 0}$, 539-551.

Lledo P. M., Vernier P., Vincent J. D., Mason W. T., and Zorec R. (1993) Inhibition of Rab3B expression attenuates $\mathrm{Ca}(2+)$-dependent exocytosis in rat anterior pituitary cells. Nature 364, 540-544.

Llinas R., Sugimori M., and Silver R. B. (1992) Microdomains of high calcium concentration in a presynaptic terminal. Science USA 256, 677-679.

Lyonnet S., Bolino A., Pelet A., Abel L., Nihoul Fekete C., Briard M. L., Mok Siu V., Kaariainen H., Martucciello G., Lerone M., et al. (1993) A gene for Hirschsprung disease maps to the proximal long arm of chromosome 10. Nat. Genet. 4, 346-350.

McMahon H. T., Bolshakov V. Y., Janz, R., Hammer R. E., Siegelbaum S. A., and Sudhof T. C. (1996). Synaptophysin, a major synaptic vesicle protein, is not essential for neurotransmitter release. Proc. Natl. Acad. Sci. USA 93, 4760-4764.

Meyer E. M. and Cooper J. R. (1983) High affinity choline uptake and calcium-dependent acetylcholine release in proteoliposomes derived from rat cortical synaptosomes. J. Neurosci. 3, 987-994.

Michaelson D. M., Ophir I., and Angel I. (1980) ATPstimulated $\mathrm{Ca}^{2+}$ transport into cholinergic Torpedo synaptic vesicles. J. Neurochem. 35, 116-124.

Misawa H., Ishii K., and Deguchi T. (1992) Gene expression of mouse choline acetyltransferase. Alternative splicing and identification of a highly active promoter region. J. Biol. Chem. 267, 20, 392-20,399.

Misawa H., Takahashi R., and Deguchi T. (1995) Coordinate expression of vesicular acetylcholine transporter and choline acetyltransferase in sympathetic superior cervical neurones. NeuroReport 6, 965-968.

Molgo J., Comella J. X., Angaut Petti D., Pecot Dechavassine M., Tabti N., Faille L., Mallart A., and Thesleff S. (1990) Presynaptic actions of botulinal neurotoxins at vertebrate neuromuscular junctions. J. Physiol. Paris 84, 152-166.

Moore M. W., Klein R. D., Farinas I., Sauer H., Armanini M., Phillips H., Reichardt L. F., Ryan A. M., Carver Moore K., and Rosenthal A. (1996) Renal and neuronal abnormalities in mice lacking GDNF Nature 382, 76-79.

Morel N., Israël M., Manaranche R., and MastourFrachon P. (1977) Isolation of pure cholinergic nerve endings from Torpedo electric organ. Evaluation of their metabolic properties. J. Cell Biol. 75, 43-55.

Morel N., Israël M., and Manaranche R. (1978) Determination of ACh concentration in Torpedo synaptosomes J. Neurochem. 30, 1553-1557.

Morimoto T., Popov S., Buckley K. M., and Poo M. M. (1995) Calcium-dependent transmitter secretion from fibroblasts: modulation by synaptotagmin I. Neuron. 15, 689-696.

Muller D. and Dunant Y. (1987) Spontaneous quantal and subquantal transmitter release at the Torpedo nerve-electroplaque junction. Neuroscience 20, 911-921.

Muller D., Garcia-Segura L. M., Parducz A., and Dunant Y. (1987) Brief occurrence of a population of large intramembrane particles in the presynaptic membrane during transmission of a nerve impulse Proc. Natl. Acad. Sci. USA 84, 590-594.

Mulligan L. M., Kwok J. B., Healey C. S., Elsdon M. J., Eng C., Gardner E., Love D. R., Mole S. E., Moore J. K., Papi L., et al. (1993) Germ-line mutations of the RET proto-oncogene in multiple endocrine neoplasia type 2A. Nature 363, $458-460$.

Nelson N. (1992) Organellar proton-ATPases. Curr. Opin. Cell. Biol. 4, 654-660.

Nonet M. L., Grundahl K., Meyer B. J., and Rand J. B. (1993) Synaptic function is impaired but not eliminated in $C$ elegans mutants lacking synaptotagmin. Cell 73, 291-1305.

Oppenheim R. W., Houenou L. J., Johnson J. E., Lin L. F., Li L., Lo A. C., Newsome A. L., Prevette D. M., and Wang S. (1995) Developing motor neurons rescued from programmed and axotomy-induced cell death by GDNF. Nature 373, 344-346.

Parducz A., Toldi J., Joo F., Siklos L., and Wolff J. R. (1987) Transient increase of calcium in pre- and postsynaptic organelles of rat superior cervical ganglion after tetanizing stimulation. Neuroscience 23, 1057-1061.

Parducz A. and Dunant Y. (1993) Transient increase in calcium in synaptic vesicles after stimulation. Neuroscience 52, 27-33.

Parducz A., Loctin F., Babel-Guérin E., and Dunant Y. (1994) Exo-endocycytotic images following tetanic stimulation at a cholinergic synapse A role in calcium extrusion? Neuroscience 62, 93-103.

Parducz A., Corrèges P., Sors P., and Dunant Y. (1997) Zinc blocks acetylcholine release but not 
vesicle fusion at the Torpedo nerve-electroplate junction. Eur. J. Neurosci. 9, 732-738.

Pasini B., Borrello M. G., Greco A., Bongarzone I., Luo Y., Mondellini P., Alberti L., Miranda C., Arighi E., Bocciardi R., et al. (1995) Loss of function effect of RET mutations causing Hirschsprung disease. Nat. Genet. 10, 35-40.

Pichel J. G., Shen L., Sheng H. Z., Granholm A. C., Drago J., Grinberg A., Lee E. J., Huang S. P., Saama M., Hoffer B. J., Sariola H., and Westphal H. (1996) Defects in enteric innervation and kidney development in mice lacking GDNF. Nature $382,73-76$.

Rothman J. E. (1994) Mechanisms of intracellular protein transport. Nature 372, 55-63.

Sagot Y., Tan S. A. Hammang J. P., Aebischer P., and Kato A. C. (1996) GDNF slows loss of motoneurons but not axonal degeneration or premature death of pmn/pmn mice. J. Neurosci. 16, 2335-2341.

Salomon R., Attie T., Pelet A., Bidaud C., Eng C., Amiel J., Samacki S., Goulet O., Ricour C., Nihoul Fekete C., Munnich A., and Lyonnet S. (1996) Germline mutations of the RET ligand GDNF are not sufficient to cause Hirschsprung disease. Nat. Genet. 14, 345-347.

Sanchez M. P., Silos Santiago I., Frisen J., He B., Lira S. A., and Barbacid M. (1996) Renal agenesis and the absence of enteric neurons in mice lacking GDNF. Nature 382, 70-73.

Schiavo G., Benfenati F., Poulain B., Rossetto O., Polverino de Laureto P., DasGupta B. R., and Montecucco C. (1992) Tetanus and botulinum-B neurotoxins block neurotransmitter release by proteolytic cleavage of synaptobrevin. Nature $359,832-835$.

Schuchardt A., D'Agati V., Larsson Blomberg L., Costantini F., and Pachnis V. (1994) Defects in the kidney and enteric nervous system of mice lacking the tyrosine kinase receptor Ret. Nature 367, 380-383.

Schuldiner S. (1994) A molecular glimpse of vesicular monoamine transporters. J. Neurochem. 62, 2067-2078.

Shiff G., Synguelakis M., and Morel N. (1996) Association of syntaxin with SNAP 25 and VAMP (synaptobrevin) in Torpedo synaptosomes. Neurochem. Int. 29, 659-667.

Siebert A., Lottspeich F., Nelson N., and Betz H. (1994) Purification of the synaptic vesicle-binding protein physophilin; identification as the $39-\mathrm{kDa}$ subunit of the vesicular $\mathrm{H}+$ ATPase J. Biol. Chem. $269,28,329-28,334$.
Sollner T. and Rothman J. E. (1994) Neurotransmission harnessing fusion machinery at the synapse. Trends Neurosci. 17, 344-348.

Sollner T., Bennett M. K., Whiteheart S. W., Scheller R. H., and Rothman J. E. (1993) A protein assembly-disassembly pathway in vitro that may correspond to sequential steps of synaptic vesicle docking, activation, and fusion. Cell 75, 409-418.

Südhof T. C. (1995) The synaptic vesicle cycle: a cascade of protein-protein interactions. Nature $375,645-653$.

Sweeney S. T., Broadie K., Keane J., Niemann H., and O'Kane C. J. (1995) Targeted expression of tetanus toxin light chain in Drosophila specifically eliminates synaptic transmission and causes behavioral defects. Neuron 14, 341-351.

Thesleff S., Molgo J., and Lundh H. (1983) Botulinum toxin and 4-aminoquinoline induce a similar abnormal type of spontaneous transmitter release at the rat neuromuscular junction. Brain Res. 264, 89-97.

Thomas L. and Betz H. (1990) Synaptophysin binds to physophilin, a putative synaptic plasma membrane protein. J. Cell Biol. 111, 2041-2052.

Tori Tarelli F., Bossi M., Fesce R., Greengard P., and Valtorta F. (1992) Synapsin I partially dissociates from synaptic vesicles during exocytosis induced by electrical stimulation. Neuron. 9, 1143-1153.

Treanor J. J., Goodman L., Sauvage de F., Stone, D. M., Poulsen K. T., Beck C. D., Gray C., Armanini M. P., Pollock R. A., Hefti F., Phillips H. S., Goddard A., Moore M. W., Buj Bello A., Davies A. M., Asai N., Takahashi M., Vandlen R., Henderson C. E., and Rosenthal A. (1996) Characterization of a multicomponent receptor for GDNF. Nature 382, 80-83.

Trupp M., Arenas E., Fainzilber M., Nilsson A. S., Sieber B. A., Grigoriou M., Kilkenny C., Salazar Grueso E., Pachnis V., Arumae U., et al. (1996) Functional receptor for GDNF encoded by the c-ret proto-oncogene. Nature 381, 785-788.

Varoqui H. and Erickson J. D. (1996) Active transport of acetylcholine by the human vesicular acetylcholine transporter. J. Biol. Chem. 271, 27, 229-27,232.

Varoqui H., Diebler M., Meunier F., Rand J. B., Usdin T. B., Bonner T. I., Eiden L. E., and Erickson J. D. (1994) Cloning and expression of the vesamicol binding protein from the marine ray Torpedo. Homology with the putative acetylcholine transporter UNC-17 from Caenorhabditis elegans. FEBS Lett. 342, 97-102. 
Varoqui H., Meunier F. M., Meunier F. A., Molgo J., Berrard S., Cervini R., Mallet J., Israël M., and Diebler M. F. (1996) Expression of the vesicular acetylcholine transporter in mammalian cells. Prog. Brain Res. 109, 83-95.

Whittaker V. P., Essman W. B., and Dowe G. H. C. (1972) The isolation of pure cholinergic synaptic vesicles from the electric organs of elasmobranch fish of the family Torpidinae. Biochem. J. 128, 833-846.

Wu D. and Hersh L. B. (1994) Choline acetyltransferase: celebrating its fiftieth year. J. Neurochem. 62, 1653-1663.

Yamamori T. K., Fukuda R., Aebersold S., Korsching M., Fann J., and Patterson P. H. (1989) The cholinergic neuronal differentiation factor from heart cells is identical to leukemia inhibitory factor. Science 246, 1412-1416.

Zhong Z. G., Misawa H., Furuya S., Kimura Y., Noda M., Yokoyama S., and Higashida $H$. (1995a) Overexpression of choline acetyltransferase reconstitutes discrete acetylcholine release in some but not all synapse formationdefective neuroblastoma cells. J. Physiol. Paris 89, 137-145.

Zhong Z. G., Kimura Y., Noda M., Misawa H., and Higashida H. (1995b) Discrete acetylcholine release from neuroblastoma or hybrid cells overexpressing choline acetyltransferase into the neuromuscular synaptic cleft. Neurosci. Res. 22, 81-88.

Zimmermann H. and Denston C. R. (1977) Recycling of synaptic vesicles in the cholinergic synapses of the Torpedo electric organ during induced transmitter release. Neuroscience 2, 695-714.

Zurn A. D., Baetge E. E., Hammang J. P., Tan S. A., and Aebischer P. (1994) Glial cell line-derived neurotrophic factor (GDNF), a new neurotrophic factor for motoneurones. NeuroReport 6, 113-118. 